\title{
Evaluating the Therapeutic Efficacy and Safety of Landiolol Hydrochloride for Management of Arrhythmia in Critical Settings: Review of the Literature
}

\author{
Yujiro Matsuishi ${ }^{1}$ \\ Bryan J Mathis $\mathbb{D}^{2}$ \\ Nobutake Shimojo' \\ Satoru Kawano (D) \\ Yoshiaki Inoue' \\ 'Department of Emergency and Critical \\ Care Medicine, Faculty of Medicine, \\ University of Tsukuba, Tsukuba, Ibaraki, \\ Japan; ${ }^{2}$ Medical English Communication \\ Center, Faculty of Medicine, University of \\ Tsukuba, Tsukuba, Ibaraki, Japan
}

Correspondence: Yujiro Matsuishi Department of Emergency and Critical Care Medicine, Faculty of Medicine, University of Tsukuba, Tsukuba, Ibaraki 305-8575, Japan

Tel +8I-29-853-5633

Fax $+8 \mid-29-853-3092$

Email

matsuishi.yujiro.xa@alumni.tsukuba.ac.jp
This article was published in the following Dove Press journal:

Vascular Health and Risk Management

Background: Landiolol hydrochloride, a highly cardio-selective beta-1 blocker with an ultra-short-acting half-life of 4 minutes, was originally approved by Japan for treatment of intraoperative tachyarrhythmias. This review aims to provide an integrated overview of the current state of knowledge of landiolol hydrochloride in the management of arrhythmia in critical settings.

Methods: We searched MEDLINE, EMBASE, and the Cochrane Library to retrieve relevant articles with a total of 65 records identified.

Results: The high $\beta 1$ selectivity ( $\beta 1 / \beta 2$ ratio of $255: 1$ ) of landiolol causes a more rapid heart rate (HR) decrease compared to esmolol while avoiding decreases in mean arterial blood pressure. Recently, it has been found useful in left ventricular dysfunction patients and fatal arrhythmia requiring emergency treatment. Recent random clinical trials (RCT) have revealed therapeutic and prophylactic effects on arrhythmia, and very low-dose landiolol might be effective for preventing postoperative atrial fibrillation (POAF) and sinus tachycardia. Likewise, landiolol is an optimal choice for perioperative tachycardia treatment during cardiac surgery. The high $\beta 1$ selectivity of landiolol is useful in heart failure patients as a first-line therapy for tachycardia and arrhythmia as it avoids the typical depression of cardiac function seen in other $\beta$-blockers. Application in cardiac injury after percutaneous coronary intervention (PCI), protection for vital organs (lung, kidney, etc.) during sepsis, and stabilizing hemodynamics in pediatric patients are becoming the new frontier of landiolol use.

Conclusion: Landiolol is useful as a first-line therapy for the prevention of POAF after cardiac/non-cardiac surgery, fatal arrhythmias in heart failure patients and during PCI. Moreover, the potential therapeutic effect of landiolol for sepsis in pediatric patients is currently being explored. As positive RCT results continue to be published, new clinical uses and further clinical studies in various settings by cardiologists, intensivists and pediatric cardiologists are being conducted.

Keywords: landiolol, $\beta$-blocker, management of arrhythmia

\section{Introduction}

The contribution of $\beta$-blockers in preventing refractory and urgent fatal arrhythmia and tachycardia is well known in chronic phase. Landiolol hydrochloride, a highly cardio-selective beta-1 blocker with an ultra-short-acting half-life of 4 minutes, ${ }^{1}$ is widely used in Japan under the brand name Onoact ${ }^{\circledR}$. Recently, European Union 
health authorities have approved usage under the name $\operatorname{Rapibloc}^{\circledR}$. 2,3 Landiolol was originally approved by Japan for treatment of intraoperative tachyarrhythmias ${ }^{4}$ and was later approved for tachycardia atrial fibrillation (AF) and atrial flutter (AFL) during left ventricular (LV) dysfunction in November 2013. ${ }^{5}$ More recently, landiolol expanded its utility into usage for fatal arrhythmia requiring emergency treatment in $2019^{6}$ and is fast becoming a reliable therapeutic choice for management of arrhythmia in acute phase. The aim of this review is to provide an integrated overview of the current state of knowledge of landiolol hydrochloride and the management of arrhythmia in critical settings.

\section{Review Process}

We searched MEDLINE (via PubMed), EMBASE, and the Cochrane Library to retrieve relevant articles for the literature review and relevant data. We used the search term "landiolol" for articles published before January 2020 with no language limitations. We explored observational studies and randomized clinical trials (RCTs) exploring the following topics: 1) pharmacokinetics and pharmacodynamics, 2) the role of prophylactic landiolol in non-cardiac surgeries, 3) the role of prophylactic landiolol in percutaneous coronary intervention, 4) the role of prophylactic landiolol in heart failure patients, 5) the role of prophylactic landiolol in sepsisinduced fatal arrhythmia, 6) and the role of prophylactic landiolol in pediatric patients.

A total of 951 records were identified in all searches (MEDLINE: 342, EMBASE: 602, the Cochrane Library: 2, manual search: 5). After excluding duplicate studies $(\mathrm{n}=326)$, we screened 625 studies. A further 560 were excluded for the following reasons: 157 were some other publication type; 403 studies were not relevant to the topic or had small sample numbers not rigorous enough for significant conclusions. A total of 65 records were thus eligible for final reviewing. The identified core studies are in Supplementary File 1.

\section{Pharmacokinetics and Pharmacodynamics}

Landiolol hydrochloride has a $\beta 1 / \beta 2$ ratio of $255{ }^{7}$ and, compared to propranolol, its $\beta 1$-selectivity is $74-380$ times greater while it has a 33-263 times greater $\beta 1$ affinity than esmolol. ${ }^{8}$ This high $\beta 1$-selectivity results in a more potent negative chronotropic effect and a less potent hypotensive effect. ${ }^{7}$ Work in rabbit animal models revealed a more rapid HR decrease with landiolol than with esmolol while the decrease in mean arterial blood pressure (MAP) seen with esmolol was not observed with landiolol. ${ }^{9}$ Similar results were obtained in isolated rabbit ${ }^{10}$ and guinea pig hearts. ${ }^{11}$

Landiolol metabolism is mainly in the liver (approximately half) and plasma and is predominantly catalyzed by liver carboxylesterase and plasma pseudocholinesterase. ${ }^{12}$ In hepatically impaired patients, maximum concentration (Cmax) and area under the concentration (AUC)-time curve values were $42 \%$ and $44 \%$ higher, respectively, but half-life did not differ compared with healthy patients and no drug-related adverse events were observed. ${ }^{13}$ A standardized method for detecting pharmacokinetics in plasma with liquid chromatography-tandem mass spectrometry (LC MS-MS) in humans ${ }^{14}$ has yielded pharmacokinetics and pharmacodynamics for Japanese, ${ }^{1}$ Chinese ${ }^{15}$ and Caucasian healthy ${ }^{16}$ and acute-phase AF/AFL populations. ${ }^{17}$ Table 1 summarizes pharmacokinetics by population.

\section{Role of Prophylactic Landiolol in Non-Cardiac Surgeries}

Several observational studies have reported on landiolol for management of postoperative atrial fibrillation (POAF). In esophageal cancer patients, POAF is a common complication after esophagectomy ${ }^{18}$ and is associated with longer hospital stays, complications, ${ }^{19}$ and mortality. ${ }^{20}$ Three RCTs of landiolol for POAF have been completed. Yoshida et al conducted a 79-patient study where landiolol was administered at $5 \mu \mathrm{g} / \mathrm{kg} / \mathrm{min}$ for $24 \mathrm{~h}$ after induction of anesthesia, then compared the AF incidents with a control group. ${ }^{21}$ POAF occurred in one control patient, leading to the conclusion that prophylactic $24 \mathrm{~h}$ low-dose landiolol was not superior to nontreatment. Ojima et al also administered landiolol at $3 \mu \mathrm{g} / \mathrm{kg} /$ min from post-operative day (POD) 1 for $72 \mathrm{~h}$ and, when compared to a placebo group of 100 patients, use of landiolol significantly reduced the incidence of POAF within the first postoperative week (incidence: landiolol: $30 \%$ vs placebo: $10 \%, \mathrm{p}=0.012$ ) and the overall incidence of postoperative complications (incidence: landiolol: $40 \%$ vs placebo: $60 \%$, $\mathrm{p}=0.046) .{ }^{22}$ Horikoshi et al administered landiolol at $5 \mu \mathrm{g} / \mathrm{kg} /$ min from the induction of anesthesia until the morning of POD 1 and use of landiolol significantly reduced the incidence of POAF (incidence: landiolol: $5.3 \%$ vs placebo: $35 \%$, $\mathrm{p}<0.05$ ) and also sinus tachycardia (incidence: landiolol: $0 \%$ vs placebo: $25 \%, \mathrm{p}<0.05) .{ }^{23}$ Moreover, they evaluated postoperative inflammation cytokines (IL-1 $\beta$, IL-6, IL-8, IL-10, 


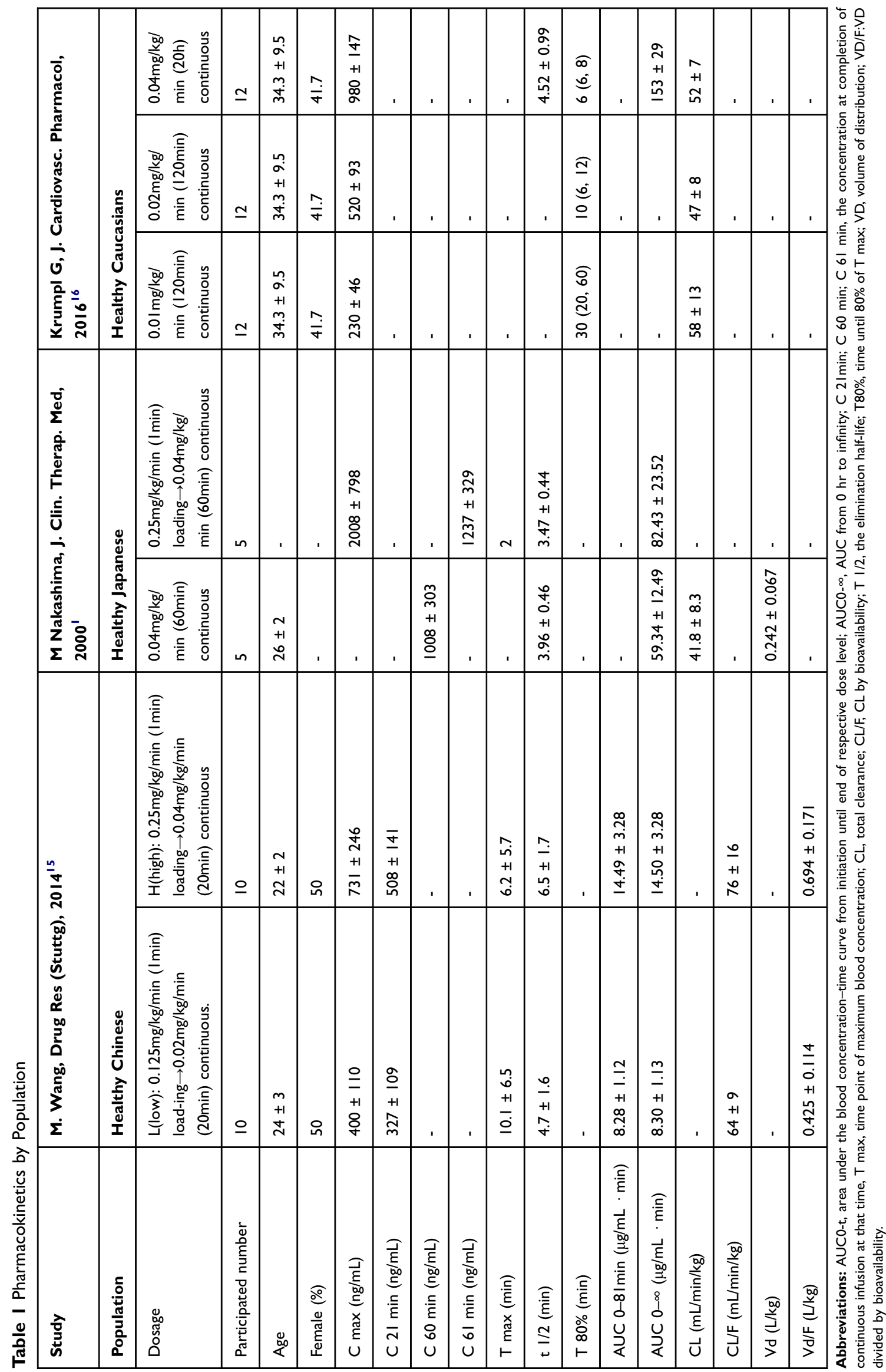


and TNF- $\alpha$ ) and use of landiolol significantly suppressed IL6 elevation but not other cytokines.

From these RCT results, one study found no superiority for prophylactic usage, but this study suffered from low statistical power and other studies showed significance in preventing POAF. Therefore, very low-dose landiolol might be effective for preventing POAF and sinus tachycardia in addition to suppressing IL-6 elevation after surgery.

\section{Role of Prophylactic Landiolol in Cardiac Surgeries}

There are several observational studies that have used landiolol to manage perioperative arrhythmia and reported prophylactic effects against POAF, ${ }^{24-30}$ treatment of POAF, ${ }^{31}$ treatment of supraventricular tachycardia (SVT), ${ }^{32}$ different treatment effects between AF and AFL/atrial tachycardia (AT), ${ }^{33}$ safe decreases in HR and improvement of hemodynamics in patients receiving catecholamine. ${ }^{34}$

RCTs have already been conducted to study the effect of landiolol on prevention of POAF after cardiac surgery (Table 2). For off-pump CABG, Nagaoka et al dosed 0.5 to $2 \mu \mathrm{g} / \mathrm{min} / \mathrm{kg}$ until PO drug start and compared the POAF incidence with the use of diltiazem ( 0.5 to $2 \mu \mathrm{g} / \mathrm{min} / \mathrm{kg}$ until PO drug start), finding that landiolol significantly reduced the incidence of POAF (landiolol: $4.8 \%$ vs diltiazem: $27 \%$, $\mathrm{p}<0.05){ }^{35}$ Fujii et al also reported a prophylactic effect of landiolol for POAF until PO $\beta$-blocker (carvedilol) start (landiolol:11.1\% vs placebo: $32.3 \%, \mathrm{p}<0.05) .{ }^{36}$ Ogawa et al reported both on the prophylactic effect of landiolol for POAF (landiolol: 19\% vs placebo: $37 \%, \mathrm{p}<0.05$ ) and for tachycardia (landiolol: 13\% vs placebo: $32 \%, \mathrm{p}<0.05$ ) without increasing bradycardia (landiolol: $15 \%$ vs placebo: $13 \%, \mathrm{p}=0.99) .^{37}$

For coronary artery bypass grafting $(\mathrm{CABG})$ with cardiopulmonary bypass (CPB), the PASCAL Trial conducted by Sezai et al showed a significant prophylactic effect of landiolol for preventing POAF compared with placebo (landiolol: $10 \%$ vs placebo: $34.3 \%, \mathrm{p}<0.05){ }^{38}$ The same group also conducted an RCT named the BABYLON Trial for CABG on CPB patients with three groups (Group L: landiolol 5mg/ $\mathrm{kg} / \mathrm{min}$ for 3 days, Group LB: landiolol $5 \mathrm{mg} / \mathrm{kg} / \mathrm{min}$ for 3 days, then bisoprolol $2.5 \mathrm{mg} /$ day PO for 2 days, Group C: placebo) that compared POAF incidence. ${ }^{39}$ Using both landiolol and bisoprolol significantly reduced the incidence of POAF compared with placebo. (Group L: 14.7\% vs Group LB: $9.1 \%$ vs Group C: $34.3 \%, \mathrm{p}<0.05$ compared with Group LB and Group C).
For valve surgery, Sakaguchi et al conducted an $\mathrm{RCT}^{40}$ using landiolol $40 \mu \mathrm{g} / \mathrm{kg} / \mathrm{min}$ for $72 \mathrm{~h}$ and saw significant reductions in POAF incidence compared with placebo. (landiolol: $20 \%$ vs control: $53.3 \%, \mathrm{p}<0.05)^{40}$ Sezai et al conducted a RCT trial named the PLATON Trial for evaluating the prophylactic effect of landiolol in cardiac surgery under CPB in LV dysfunction [Ejection fraction (EF) $>35 \%$ ] patients. $^{41}$ The use of landiolol $2 \mu \mathrm{g} / \mathrm{kg} / \mathrm{min}$ for at least 2 days significantly reduced the incidence of POAF compared with no landiolol use (landiolol: $10 \%$ vs placebo: $40 \%, \mathrm{p}<0.05$ ) without significant decreases in HR and blood pressure.

Landiolol not only prevents POAF may be useful for treatment of POAF as well. Sakamoto et al conducted an RCT using landiolol at $0.5-40 \mu \mathrm{g} / \mathrm{kg} / \mathrm{min}$ for treatment of POAF in CABG and valve surgery and observed significant reductions of POAF recurrence compared with diltiazem (landiolol: $11.5 \%$ vs diltiazem: $27.2 \%)^{42}$

Recent meta-analysis of landiolol with regard to prophylactic effect against POAF after cardiac surgery reported significant reductions in the risk of onset POAF [overall cardiac surgery: odds ratio (OR): 0.27 ; 95\% confidence interval (CI): $0.18-0.42$, cardiac surgery on $\mathrm{CPB}$ : OR: 0.23; 95\% CI: 0.13-0.40, off-pump CABG: OR: 0.36; 95\% CI: $0.19-0.70]$ but not mortality and complication risk (mortality: OR: 0.45; 95\% CI: 0.07-2.74, complication: OR: 0.45 ; 95\% CI: $0.16-1.23) .{ }^{43}$ From these diverse RCT and meta-analysis results, very low-dose landiolol might be effective for preventing POAF but has not been observed to change the risk of mortality and complications.

\section{Role of Prophylactic Landiolol in Percutaneous Coronary Intervention}

There is limited and conflicting knowledge about the effect of landiolol during percutaneous coronary intervention (PCI). An observational study reported that landiolol use just before reperfusion at $3 \mu \mathrm{g} / \mathrm{kg} / \mathrm{min}$ was an independent predictor of an ST-segment resolution (STR) ${ }^{44}$ and prevented Killip class grade progression ${ }^{44}$ but one study reported associated hypotension ${ }^{44}$ while another reported no serious complications. ${ }^{45}$ Hanada et al conducted an RCT that used landiolol during PCI at $3 \mu \mathrm{g} / \mathrm{kg} / \mathrm{min}$ without loading and continued for $24 \mathrm{~h}$ just after PCI. ${ }^{46}$ Landiolol use significantly reversed LVEF from acute phase to chronic phase (LVEF: landiolol: $49.1 \%$ to $52.0, \mathrm{p}=0.01$, control $50.2 \%$ to $50.2 \%, p=0.99$ ) but did not significantly alter the incidence of arrhythmias in the first $24 \mathrm{~h}$ after PCI (Sustained ventricular tachycardia (VT)/Ventricular fibrillation (VF): landiolol: 0\% 
Table 2 Therapeutic and Prophylactic Effects of Landiolol During Cardiac Operation in Randomized Control Trials

\begin{tabular}{|c|c|c|c|c|c|c|c|c|}
\hline Author & Year & $\begin{array}{l}\text { Study } \\
\text { Name }\end{array}$ & $\begin{array}{l}\text { Type of } \\
\text { Surgery }\end{array}$ & $\begin{array}{l}\text { Landiolol } \\
\text { Dose }\end{array}$ & $\begin{array}{l}\text { Compare } \\
\text { Drag }\end{array}$ & Participants & POAF & Adverse Effects \\
\hline \multicolumn{9}{|c|}{ Treatment of POAF } \\
\hline Sakamoto et $\mathrm{al}^{42}$ & 2012 & $\begin{array}{l}\text { JL-KNIGHT } \\
\text { Study }\end{array}$ & $\begin{array}{l}\text { CABG, } \\
\text { valve } \\
\text { replacement }\end{array}$ & $0.5-40 \mu \mathrm{g} / \mathrm{kg} / \mathrm{min}$ & $\begin{array}{l}\text { DIL: bolus } \\
\text { dose of } \\
0.25 \mathrm{mg} / \mathrm{kg} \\
\text { over } 2 \mathrm{~min} \text {, } \\
3-15 \mathrm{mg} / \mathrm{h}\end{array}$ & $\begin{array}{l}\text { LAN:35 } \\
\text { DIL:36 }\end{array}$ & $\begin{array}{l}\text { Incidence: LAN: I I.5\% } \\
\text { vs DIL:27.2\%, } \\
\text { Conversion to sinus } \\
\text { rhythm (<8h): } \\
\text { LAN:54.3\% vs } \\
\text { DIL:30.6\%*, HR } \\
\text { controlled, but not } \\
\text { converted (<8): } \\
\text { LAN:62.9\% vs } \\
\text { DIL:50\% }\end{array}$ & $\begin{array}{l}\text { Hypotension: } \\
\text { LAN:I I.4\% vs } \\
\text { DIL:30.6\%*, } \\
\text { Bradycardia: LAN:0\% } \\
\text { vs DIL:II. I\%*, ICU } \\
\text { stay (days): LAN:3.9 vs } \\
\text { DIL:3.4. Bradycardia: } \\
\text { LAN:0\% vs DIL:II. I\% } \\
\text { *. ICU stay (days): } \\
\text { LAN:3.9 vs DIL:3.4. }\end{array}$ \\
\hline \multicolumn{9}{|c|}{ Prevention of POAF in $\mathrm{CABG}$ on $\mathrm{CPB}$} \\
\hline Sezai $A$ et al ${ }^{38}$ & 2011 & $\begin{array}{l}\text { PASCAL } \\
\text { Trial }\end{array}$ & $\begin{array}{l}\text { CABG on } \\
\text { pump }\end{array}$ & $\begin{array}{l}\text { Started at } 2 \mu \mathrm{g} / \\
\mathrm{kg} / \mathrm{min} \text { and dis- } \\
\text { continued after } \\
48 \mathrm{~h}\end{array}$ & Placebo & $\begin{array}{l}\text { LAN:70 } \\
\text { placebo:70 }\end{array}$ & $\begin{array}{l}\text { Incidence: LAN: } 10 \% \\
\text { vs Placebo:34.3\%* }\end{array}$ & $\begin{array}{l}\text { Mortality: } 0 \% \text { vs. } 2.8 \% \text {, } \\
\text { Complications: } 4.2 \% \text { vs } \\
8.5 \% \text {, Hospital stay } \\
\text { (days): } 11.2 \text { vs } 14.0^{*}\end{array}$ \\
\hline Sezai $A$ et a $\left.\right|^{39}$ & 2012 & $\begin{array}{l}\text { BABYLON } \\
\text { trial }\end{array}$ & $\begin{array}{l}\text { CABG on } \\
\text { pump }\end{array}$ & $\begin{array}{l}\text { Group L: using } \\
\text { LAN } 5 \mathrm{mg} / \mathrm{kg} / \\
\text { min for } 3 \text { days, } \\
\text { Group LB:using } \\
\text { LAN } 5 \mathrm{mg} / \mathrm{kg} / \\
\text { min for } 3 \text { days, } \\
\text { then BIS } 2.5 \mathrm{mg} / \\
\text { day PO for } 2 \\
\text { days }\end{array}$ & $\begin{array}{l}\text { Group C: } \\
\text { placebo }\end{array}$ & $\begin{array}{l}\text { Group L:34 } \\
\text { Group LB:33 } \\
\text { Group C:34 }\end{array}$ & $\begin{array}{l}\text { Incidence: Group } \\
\text { L: } 14.7 \% \text { vs Group } \\
\text { LB:9.1\%* vs Group } \\
\text { C:34.3\% }\end{array}$ & $\begin{array}{l}\text { Mortality:Group } \\
\text { L:2.9\% vs Group LB:0\% } \\
\text { vs Group C:0\%, } \\
\text { Complications:Group } \\
\text { L:5.8\% vs Group LB:9\% } \\
\text { vs Group C:8.8\%, } \\
\text { Hospital stay (days): } \\
\text { Group L: I I.8 vs Group } \\
\text { LB: I I vs Group C: } 12\end{array}$ \\
\hline \multicolumn{9}{|c|}{ Prevention of POAF in Off-Pump CABG } \\
\hline Fujii et $a^{36}$ & 2012 & & $\begin{array}{l}\text { CABG off } \\
\text { pump }\end{array}$ & $\begin{array}{l}5 \text { (range 0-10) } \\
\mu g / \mathrm{kg} / \mathrm{min} \text { untill } \\
\text { PO drug start } \\
\text { then CAR } 2.5- \\
5 \mathrm{mg} / \text { day PO } \\
\text { continued } \\
\text { postoperatively }\end{array}$ & $\begin{array}{l}\text { Placebo untill } \\
\text { PO drug start } \\
\text { then CAR } 2.5- \\
5 \mathrm{mg} / \text { day PO } \\
\text { continued } \\
\text { postoperatively }\end{array}$ & $\begin{array}{l}\text { LAN:36 } \\
\text { placebo:34 }\end{array}$ & $\begin{array}{l}\text { Incidence: LAN:I I.I\% } \\
\text { vs Placebo:32.3\%* }\end{array}$ & - \\
\hline Ogawa $S$ et al ${ }^{37}$ & 2012 & & $\begin{array}{l}\text { CABG off } \\
\text { pump }\end{array}$ & $\begin{array}{l}3-5 \mu g / \mathrm{kg} / \mathrm{min} \\
\text { for } 2 \text { days }\end{array}$ & Not using LAN & $\begin{array}{l}\text { LAN:68 } \\
\text { control:68 }\end{array}$ & $\begin{array}{l}\text { Incidence: LAN:19\% } \\
\text { vs Control:37\%* }\end{array}$ & $\begin{array}{l}\text { Tachycardia:LAN:13\% } \\
\text { vs Control:32\%*, } \\
\text { Bradycardia:LAN:15\% } \\
\text { vs Control:13\%, }\end{array}$ \\
\hline Nagaoka et al ${ }^{35}$ & 2014 & & $\begin{array}{l}\text { CABG off } \\
\text { pump }\end{array}$ & $\begin{array}{l}0.5 \text { to } 2 \mu \mathrm{g} / \mathrm{min} / \\
\mathrm{kg} \text { untill } \mathrm{PO} \\
\text { drug start }\end{array}$ & $\begin{array}{l}\text { DIL:0.5 to } 2 \\
\mu \mathrm{g} / \mathrm{min} / \mathrm{kg} \text { untill } \\
\text { PO drug start }\end{array}$ & $\begin{array}{l}\text { LAN:2I } \\
\text { DIL:22 }\end{array}$ & $\begin{array}{l}\text { Incidence: LAN:4.8\% } \\
\text { vs DIL:27\%* }\end{array}$ & - \\
\hline \multicolumn{9}{|c|}{ Prevention of POAF on Valve Surgery } \\
\hline $\begin{array}{l}\text { Sakaguchi } \\
M \text { et al }{ }^{40}\end{array}$ & 2012 & & $\begin{array}{l}\text { Valve } \\
\text { Surgery }\end{array}$ & $\begin{array}{l}10 \mu \mathrm{g} / \mathrm{kg} / \mathrm{min} \text { for } \\
72 \mathrm{~h}\end{array}$ & Not using LAN & $\begin{array}{l}\text { LAN:30 } \\
\text { control:30 }\end{array}$ & $\begin{array}{l}\text { Incidence: LAN:20\% } \\
\text { vs Control:53.3\%** }\end{array}$ & - \\
\hline $\begin{array}{l}\text { Prevention of PO } \\
\text { Dysfunction }\end{array}$ & on $\mathrm{Ca}_{\mathrm{a}}$ & ac Surgery & & & & & & \\
\hline
\end{tabular}

(Continued) 
Table 2 (Continued).

\begin{tabular}{|l|l|l|l|l|l|l|l|l|}
\hline Author & Year & $\begin{array}{l}\text { Study } \\
\text { Name }\end{array}$ & $\begin{array}{l}\text { Type of } \\
\text { Surgery }\end{array}$ & $\begin{array}{l}\text { Landiolol } \\
\text { Dose }\end{array}$ & $\begin{array}{l}\text { Compare } \\
\text { Drag }\end{array}$ & Participants & POAF & Adverse Effects \\
\hline Sezai A et al $\left.\right|^{41}$ & 2015 & $\begin{array}{l}\text { PLATON } \\
\text { trial }\end{array}$ & $\begin{array}{l}\text { Cardiac } \\
\text { surgery } \\
\text { under CPB } \\
\text { and had LV } \\
\text { dysfunction } \\
\text { (EF }>35 \%)\end{array}$ & $\begin{array}{l}2 \mu \mathrm{g} / \mathrm{kg} / \mathrm{min} \text { at } \\
\text { least 2 days }\end{array}$ & Not using LAN & $\begin{array}{l}\text { LAN:30 } \\
\text { control:30 }\end{array}$ & $\begin{array}{l}\text { Incidence: LAN: } 10 \% \\
\text { vs Control:40\%* }\end{array}$ & $\begin{array}{l}\text { In-hospital death: } \\
\text { LAN:0\% vs } \\
\text { Control:6.6\%, } \\
\text { Complications: } \\
\text { LAN:3.3\% vs } \\
\text { Control: } 13.3 \%, \text { ICU } \\
\text { stay (days): LAN:4.I vs } \\
\text { Control:4.3, Hospital } \\
\text { stay (days): I4.6 vs } \\
\text { 19.4* }\end{array}$ \\
\hline
\end{tabular}

Note: ${ }^{*}<0.05$, if the ones with no $*$ are not statistically significant.

Abbreviations: BIS, bisoprolol; CABG, coronary artery bypass grafting; CAR, carvedilol; CPB, cardiopulmonary bypass; DIL, diltiazem; LAN, landiolol; PO, oral administration; ICU, Intensive care unit.

vs control: $0 \%$, unsustained VT: landiolol:34\% vs control: 22\%, newly developed AF: landiolol: $2 \%$ vs control: $2 \%$ ). One patient in the landiolol group showed bradycardia at a rate of 50 beats/min at $12 \mathrm{~h}$ after administration, recovering approximately $10 \mathrm{~min}$ after discontinuation of the drug. Park et al also conducted an RCT using landiolol during PCI but administered it over $1 \mathrm{~min}$ in an intracoronary fashion $(0.06 \mathrm{mg} / \mathrm{kg})$ via an Over-the-Wire balloon catheter before and after balloon inflation. ${ }^{47}$ They then intravenously administered landiolol $(0.02 \mathrm{mg} / \mathrm{kg} / \mathrm{min})$ after the last stent deployment and continued for $6 \mathrm{~h}$ after PCI. This preserved the $\mathrm{LV}$ wall motion score index ( $\mathrm{LV}$ wall motion score index change from pre-PCI: landiolol:0.00 vs control: -0.01 , $\mathrm{p}<0.05)$ and decreased cardiac troponin-I (cTnI) to $\geqq 0.12$ $\mathrm{ng} / \mathrm{mL}$ after PCI (incidence of $\mathrm{cTnI} \geqq 0.12 \mathrm{ng} / \mathrm{mL}$ : landiolol: $41 \%$ vs control: $70 \%, \mathrm{p}=0.016$ ). As $\mathrm{cTnI} \geqq 0.12 \mathrm{ng} / \mathrm{mL}$ is considered as MI status in elective $\mathrm{PCI},{ }^{48}$ landiolol can thus reduce the incidence of PCI-related MI.

From these results, observational studies and RCTs (Table 3) using continuous landiolol for $24 \mathrm{~h}$ just after PCI via intracoronary administration before and after balloon inflation potentially protect against arrhythmia and cardiac injury after PCI.

\section{Role of Prophylactic Landiolol in Heart Failure Patients}

Risks and benefits of using $\beta$-blockers for heart failure (HF) patients must be carefully weighed. Several observational studies and RCTs using landiolol for HF patients with regard to infusion-to-oral beta-blocker (BB) therapy commencement have shown HR reduction without markedly decreasing blood pressure ${ }^{49,50}$ compared to diltiazem. $^{51}$

Additionally, combination-therapy, lower-dose landiolol with milrinone has a potentially beneficial effect for acute decompensated heart failure (ADHF) patients. Kobayashi et al conducted a study for ADHF (both depressed $\mathrm{LV}$ function $[\mathrm{EF} \leq 0.35]$ and $\mathrm{HR}>90 \mathrm{bpm}$ with sinus rhythm, not receiving i.v. inotropes, and the absence of specific devices) in tachycardia patients and revealed that lower-dose landiolol $(1.5 / \mu \mathrm{g} / \mathrm{kg} / \mathrm{min})$ with milrinone $(0.25-0.5 \mu \mathrm{g} / \mathrm{kg} / \mathrm{min})$ increased hemodynamic parameters, including pulmonary capillary wedge pressure (PCWP), stroke volume index (SVI), and oxygen saturation of mixed venous blood ( $\mathrm{SvO} 2){ }^{52}$ This effect disappeared at higher doses of landiolol $(\geq 3.0 / \mu \mathrm{g} / \mathrm{kg} / \mathrm{min}){ }^{52}$ Kobayashi et al also conducted animal experiments using a canine heart failure model to determine the mechanism of this combination therapy. They administered various doses $(0$ $\mathrm{nM}$ to $1000 \mathrm{nM}$ ) of landiolol then measured cardiomyocyte cell shortening (CS) and intracellular $\mathrm{Ca}^{2+}$ transients (CaT). $\mathrm{Ca}^{2+}$ spikes were measured and the presence or absence of milrinone and heart failure were correlated (three factors; 8 patterns in total). They observed that simultaneous administration of both landiolol and milrinone to failing cardiomyocytes did not decrease cardiomyocyte function but significantly decreased the frequency of diastolic $\mathrm{Ca}^{2+}$ spikes (CaSF) with further increases in sarcoplasmic reticulum $\mathrm{Ca}^{2+}$ concentration while peak $\mathrm{CaT}$ and $\mathrm{CS}$ improved compared with administration of milrinone alone. ${ }^{53}$ Moreover, landiolol had no effect on levels of phosphorylated PLB (Ser16 and Thr17) but suppressed the hyperphosphorylation of RyR2. 


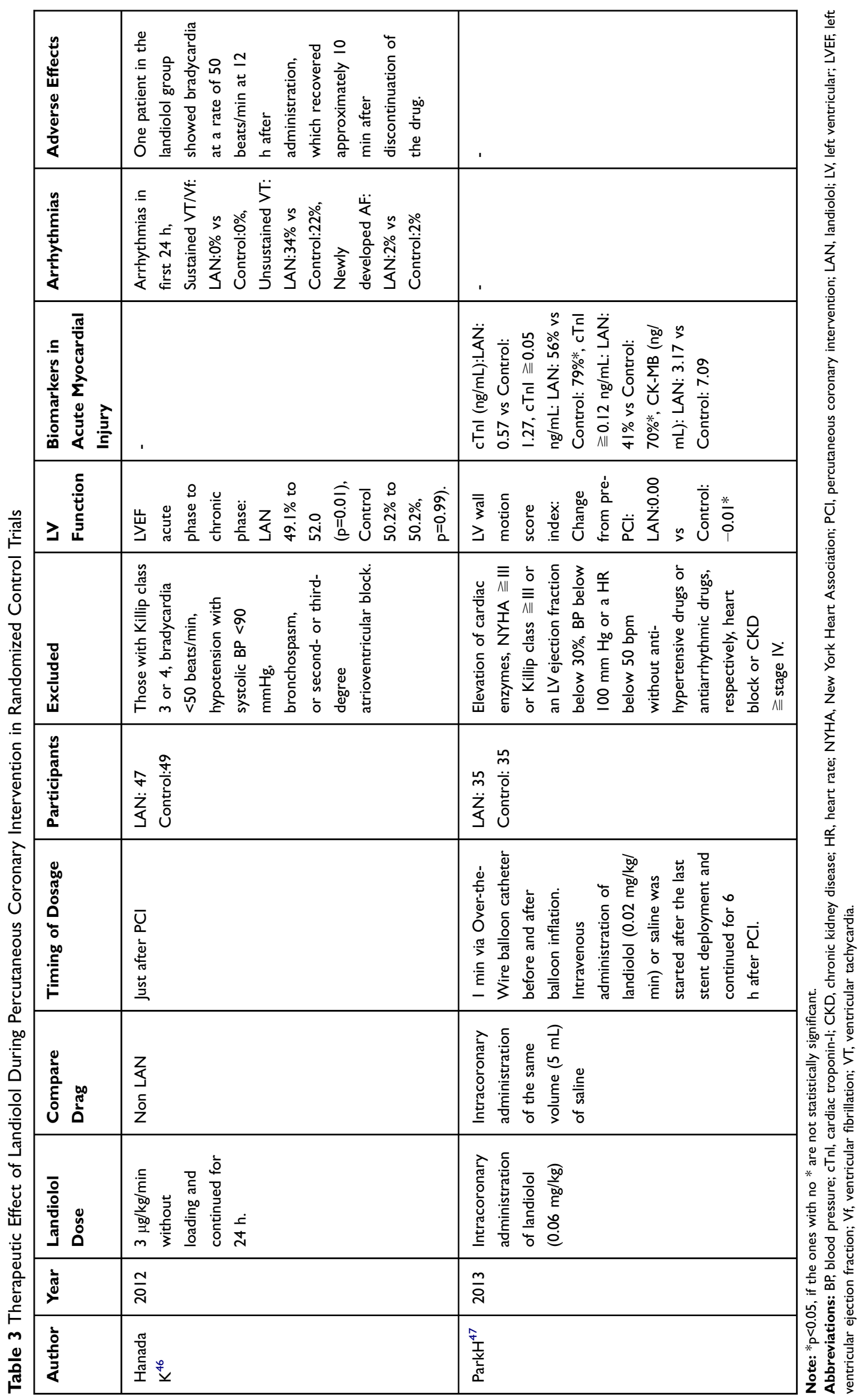


From these results, they concluded that improved function in failing cardiomyocytes was via inhibition of the phosphorylation of ryanodine receptor 2 (RyR2) and subsequent diastolic Ca2+leakage. ${ }^{53}$

An RCT conducted by Nagai et al named the J-Land Study dosed 1-10 $\mu \mathrm{g} / \mathrm{min} / \mathrm{kg}$ of landiolol for patients with AF/AFL (over HR $\geq 120$ beats/min), with low EF (LVEF: 25-50\%) and compared the achievement rate of the primary end point (both HR $<110$ beats/min and $\geq 20 \%$ decrease from baseline at $2 \mathrm{~h}$ after administration) with digoxin. ${ }^{54}$ The landiolol group achieved a significantly higher rate of reaching the primary endpoint (Achievement rate of primary endpoint: landiolol: 48\% vs digoxin: $13.9 \%, \mathrm{p}<0.0001)$ with an average landiolol dosage of $6.7 \pm 3.2 \mu \mathrm{g} / \mathrm{kg} / \mathrm{min}$. Wada et al ${ }^{55}$ also conducted an observational study for LV dysfunction patients using the same primary endpoint and reported $74 \%$ of patients were responsive for $\mathrm{AF} / \mathrm{AFL}$ and $58 \%$ of patients were responsive for VTs. ${ }^{55}$

From the safety aspect of dosing landiolol in HD patients, several studies have reported adverse events. One observational study ${ }^{56}$ used landiolol at an infusion rate of $1 \mathrm{~g} / \mathrm{kg} / \mathrm{min}$ for $52 \mathrm{HF}$ patients and 3 patients experienced transient asymptomatic hypotension requiring cessation (average dose of landiolol: $10.8 \pm 9.4 \mathrm{~L} \mathrm{~g} / \mathrm{kg} / \mathrm{min}$ ) while another reported that hypotension after landiolol treatment occurred in about $10 \%$ of patients with $\mathrm{AF}$, AFL, or AT ventricular response 120 bpm refractory 12 VTs. ${ }^{55}$ In the J-Land Study, the prevalence of adverse events over the total observational time was not significantly different between landiolol and digoxin groups (adverse events over total observational time: landiolol: $32.3 \%$, digoxin: $32.7 \%, \mathrm{p}=0.95$ ), but the landiolol group experienced a significantly higher prevalence of adverse events over a 2-h treatment period (adverse events over a 2-h treatment period: landiolol: $8.6 \%$, digoxin: $1.9 \%$, $\mathrm{p}=0.029) .{ }^{54}$ These events included 2 serious adverse events (congestive heart failure and embolic stroke). In 3 digoxin group patients, sinus arrest, diabetes insipidus, and pneumonia occurred while 3 landiolol group patients experienced embolic stroke, hypotension, and asthma. All of these patients had to discontinue therapy because of these serious adverse events. However, another conflicting study reported no adverse events observed during the study period. ${ }^{50}$

From these results of observational studies and RCT, landiolol is useful as a first-line therapy in HF patients but careful observation is needed to maintain hemodynamic status.

\section{Role of Prophylactic Landiolol in Sepsis-Induced Fatal Arrhythmia}

Sepsis is a severe critical status and inflammatory immune reaction that causes multiple organ dysfunction syndrome (MODS). Sepsis-related cardiac dysfunction is a fatal consequence of sepsis first described in $1981^{57}$ and can be diagnosed in up to $60 \%$ of patients with septic shock. ${ }^{58}$ There are several mechanisms that transduce this cardiac dysfunction, including downregulation of $\beta$-adrenergic receptors, ${ }^{59-61}$ and use of $\beta-1$ agonists (eg, dobutamine) was reported to be ineffective in sepsis ${ }^{62}$ due to failing systemic oxygen delivery ${ }^{63}$ while catecholamine vasopressor therapy would increase cardiac adverse events. ${ }^{64}$ In addition, tachycardia was associated with a poor outcome in sepsis patients. Therefore, preserving heart load and HR has been considered as a potential treatment for sepsis, as evidenced by use of $\beta$-adrenergic blocker esmolol that was reported to significantly decrease mortality in patients with septic shock in a recent $\mathrm{RCT}^{65}$ (esmolol: $49.4 \%$ vs control: $80 \%, \mathrm{p}<0.001)$.

Esmolol is already reported to have a therapeutic effect against sepsis in animal models ${ }^{66-68}$ and landiolol treatment has shown significant decreases in serum TNF- $\alpha$ and IL-6 with increased cardiac function in a lipopolysaccharide (LPS)-induced rat model. ${ }^{69,70}$ Seki et al evaluated the cardioprotection of landiolol in an LPS-induced, systemically inflamed rat model. Continuous landiolol administration significantly reduced cardiac tumor necrosis factor- $\alpha$ (TNF- $\alpha$ ) levels and the percentage of fractional shortening in the murine hearts was significantly increased. Endothelin-1 (ET-19), a potent vasoconstrictor implicated in pathogenesis of sepsis, was normalized by landiolol treatment and the authors concluded that landiolol has a cardioprotective effect possibly modulated by cardiac vasoactive peptides such as ET. ${ }^{68}$ Hagiwara et al also used LPS-induced, systemically inflamed rats to evaluate cardioprotective effects of landiolol and found it to both normalize cardiac function and significantly reduce serum levels of High-mobility group box 1 (HMGB-1), an inflammatory mediator critical to the development of sepsis. Surprisingly, it was reported that landiolol ameliorates not only heart but also kidney ${ }^{71,72}$ and lung ${ }^{73}$ damage in animal sepsis models. However, Kurita et al revealed that landiolol administration causes reductions in cerebral tissue oxygenation ${ }^{74}$ in an LPS-induced, 
systemically inflamed swine model by measuring hemodynamics, blood variables, and cerebral tissue oxygenation index (TOI) by near-infrared spectroscopy. They revealed that landiolol reduces LPS-induced tachycardia but induces thermodynamic depression depending on the endotoxemia stage. This reduction was especially seen when SV did not increase in response to the decrease in HR. Interestingly, sexmediated responses were observed in an animal study by Mathieu et al where landiolol was tested in a cecal ligation and puncture (CLP) sepsis model in both male and female rats. $^{75}$ Landiolol increased SVI compared with non-treated sepsis rats in males but not females. This sex-mediated response for $\beta$-blockers after high-risk vascular surgery has already been clinically reported. ${ }^{76}$

Clinically, several case reports reported successful management of tachycardiac atrial fibrillation in sepsis patients with landiolol. ${ }^{77,78}$ An on-going RCT is currently using landiolol for sepsis patients has set the primary endpoint as HR response ( $\mathrm{HR}=80-94 \mathrm{bpm})$ and maintenance without increases in vasopressor requirement was observed during the first $24 \mathrm{~h}$ after administration. ${ }^{79}$

From these results of animal studies and clinical reports, use of landiolol for sepsis reveals the therapeutic effect of rate control during sepsis and a subsequent beneficial effect for other vital organs.

\section{Role of Prophylactic Landiolol in Pediatric Patients}

There is a new appreciation for the need of landiolol in pediatric patients. In adult patients, both esmolol and landiolol are used for tachycardia rate control because of high $\beta 1$ : $\beta 2$ selectivity ratios. Due to the low hemodynamic stability of pediatric patients, esmolol has been shown to control hypertension effectively in children after cardiac surgery. ${ }^{80,81}$ From this fact, it may be inferred that the higher $\beta 1: \beta 2$ selectivity of landiolol over esmolol would render it the superior choice for tachycardia treatment in pediatric patients.

Several case reports have reported the usefulness of landiolol for preventing idiopathic ventricular tachycardia in neonates ${ }^{82}$ as well as supraventricular tachycardia caused by viral myocarditis. ${ }^{83}$ Miyake et al evaluated the efficacy and safety of landiolol for tachyarrhythmia in patients undergoing the Fontan procedure (total cavopulmonary connection; TCPC). ${ }^{84}$ The average initial dose of landiolol was $4.7 \pm 2.3$ $\mu \mathrm{g} / \mathrm{kg} / \mathrm{min}$, without a loading dose, and this significantly

Table 4 Ongoing Randomized Control Trials in New Therapeutic Area

\begin{tabular}{|c|c|c|c|c|c|c|c|c|c|}
\hline Author & Year & $\begin{array}{l}\text { Study } \\
\text { Name }\end{array}$ & Age & $\begin{array}{l}\text { Disease of } \\
\text { Eligible } \\
\text { Patients }\end{array}$ & $\begin{array}{l}\text { Landiolol } \\
\text { Dose }\end{array}$ & $\begin{array}{l}\text { Compare } \\
\text { Drag }\end{array}$ & $\begin{array}{l}\text { Sample } \\
\text { Size }\end{array}$ & $\begin{array}{l}\text { Primary } \\
\text { Endpoint }\end{array}$ & Secondary Endpoint \\
\hline $\begin{array}{l}\text { Sepsis } \\
\text { Unger } \\
M \text { et } \text { al }^{79}\end{array}$ & $2018-$ & $\begin{array}{l}\text { LANDI-SEP } \\
\text { study }\end{array}$ & $\begin{array}{l}\text { Aged } \geq \\
18 \text { years }\end{array}$ & $\begin{array}{l}\text { Septic shock and } \\
\text { tachycardia (HR } \geq \\
95 \mathrm{bpm}) \text { despite } \\
\text { a hemodynamic } \\
\text { optimization } \\
\text { period of } 24 \\
36 \mathrm{~h} \text {. }\end{array}$ & $\begin{array}{l}\mathrm{I}-40 \mu \mathrm{g} / \mathrm{kg} / \\
\mathrm{min} \text { at } \\
\text { intervals of } \\
\text { at least } \\
20 \text { min to } \\
\text { obtain and } \\
\text { maintain } \\
\text { a HR of } \\
80-94 \\
\text { bpm. }\end{array}$ & $\begin{array}{l}\text { Standard } \\
\text { care }\end{array}$ & 200 & $\begin{array}{l}\text { HR response (HR } \\
=80-94 \mathrm{bpm}) \text { and } \\
\text { maintenance } \\
\text { thereof without } \\
\text { increase in } \\
\text { vasopressor } \\
\text { requirements } \\
\text { during the first } \\
24 \mathrm{~h} .\end{array}$ & $\begin{array}{l}\text { ICU and 28-day } \\
\text { mortality, ICU and } \\
\text { hospital stay duration, } \\
\text { SOFA score, and } \\
\text { inotrope and } \\
\text { vasopressor support } \\
\text { requirements. }\end{array}$ \\
\hline \multicolumn{10}{|c|}{ Pediatric Patients with Heart Failure } \\
\hline $\begin{array}{l}\text { Sumitomo } \\
\mathrm{N} \text { et } \mathrm{al}^{87}\end{array}$ & $2015-2021$ & $\begin{array}{l}\text { HEARTFUL } \\
\text { study }\end{array}$ & $\begin{array}{l}\text { Aged } \geqq \\
3 \\
\text { months } \\
\text { and }<15 \\
\text { years }\end{array}$ & $\begin{array}{l}\text { Have } \\
\text { tachyarrhythmia } \\
\text { (AF, AFL, SVT) } \\
\text { as well as heart } \\
\text { failure. }\end{array}$ & $\begin{array}{l}\mathrm{I}-10 \mu \mathrm{g} / \mathrm{kg} / \\
\min \end{array}$ & $\begin{array}{l}\text { Not } \\
\text { written }\end{array}$ & 25 & $\begin{array}{l}\geqq 20 \% \text { reduction } \\
\text { from baseline } \\
\text { heart rate or } \\
\text { return to normal } \\
\text { sinus rhythm } \\
\text { within } 2 \mathrm{~h} \text { after } \\
\text { starting } \\
\text { intravenous } \\
\text { administration. }\end{array}$ & $\begin{array}{l}\mathrm{HR} \text {, return to normal } \\
\text { sinus rhythm, } \\
\text { percentage of patients } \\
\text { with } 20 \% \text { reduction in } \\
\text { heart rate or return to } \\
\text { normal sinus rhythm, } \\
\text { and return to the resting } \\
\text { HR before the } \\
\text { arrhythmia attack. }\end{array}$ \\
\hline
\end{tabular}

Abbreviations: AF, atrial fibrillation; AFL, atrial flutter; HR, heart rate; ICU, Intensive care unit; SOFA, sequential organ failure assessment; SVT, supraventricular tachycardia. 
reduced HR without significant blood pressure decreases. Tokunaga et al also evaluated the efficacy and safety of landiolol in the management of tachyarrhythmias after pediatric cardiac surgery. An average loading dose of $11.3 \pm 4.0 \mu \mathrm{g} / \mathrm{kg} /$ min and maintenance doses of $6.8 \pm 0.9 \mu \mathrm{g} / \mathrm{kg} / \mathrm{min}$ were sufficient to achieve rate control without significant blood pressure decreases. ${ }^{85}$ Moreover, $70 \%$ of these cases experienced sinus rhythm conversion from tachyarrhythmias within an average of $2.3 \pm 0.5$ hours. They recommended low starting doses (3-5 $\mu \mathrm{g} / \mathrm{kg} / \mathrm{min}$ ) for pediatric patients in place of recommended dosing ( $40 \mu \mathrm{g} / \mathrm{kg} / \mathrm{min}$ for loading dose, $10 \mu \mathrm{g} / \mathrm{kg} / \mathrm{min}$ for maintenance dose). Yoneyama et al reported efficacy of landiolol for managing junctional ectopic tachycardia (JET) in pediatric patients who underwent open-heart surgery. The average loading dose of $8.5 \pm 3.6 \mu \mathrm{g} / \mathrm{kg} / \mathrm{min}$ and maintenance doses of $7.9 \pm 0.6 \mu \mathrm{g} / \mathrm{kg} / \mathrm{min}$ achieved rate control without significant blood pressure decreases. ${ }^{86}$ Approximately $80 \%$ patients were converted to regular sinus rhythm within 24 hours after starting administration of landiolol and 90\% patients had atrioventricular sequential pacing to maintain appropriate heart rate under landiolol suppression of the junctional heart rate.

There is one RCT conducted by Sumitomo et al named the HEARTFUL study in which landiolol was administered to prevent tachyarrhythmia in a dose starting from $1 \mu \mathrm{g} / \mathrm{kg} / \mathrm{min}$ to achieve a $20 \%$ reduction of HR in patients aged from 3 months to 15 years old patients with heart failure ${ }^{87}$ (Table 4).

Reports of landiolol usage in pediatric patients are scarce, but initial researches into the therapeutic effect of landiolol for tachyarrhythmia in pediatric patients are promising and further studies are required.

\section{Conclusion}

Landiolol, by virtue of its high $\beta 1$ selectivity, can treat arrhythmia without decreasing heart contraction and is useful as a first-line therapy for the prevention of POAF after cardiac/non-cardiac surgery, fatal arrhythmias in heart failure patients and during PCI. Moreover, the potential therapeutic effect of landiolol for sepsis and pediatric patients is currently being explored. Recent, positive RCT results will thus continue to inspire cardiologists, intensivists and pediatric cardiologists to find new uses for and conduct studies with this drug.

\section{Abbreviations}

ADHF, acute decompensated heart failure; AFL, atrial flutter; AF, atrial fibrillation; AT, atrial tachycardia; AUC, area under the concentration; $\mathrm{CaSF}$, the frequency of diastolic $\mathrm{Ca} 2$ + sparks; CaT, intracellular $\mathrm{Ca} 2+$ transients; cTnI, cardiac troponin-I; CS, cardiomyocyte cell shortening; CPB, cardiopulmonary bypass; $\mathrm{CI}$, confidence interval; $\mathrm{CABG}$, coronary artery bypass grafting; $\mathrm{EF}$, ejection fraction; HR, heart rate; $\mathrm{HF}$, heart failure; LV, left ventricular; Cmax, maximum concentration; MAP, mean arterial blood pressure; MODS, multi-organ dysfunction syndrome; OR, odds ratio; $\mathrm{SvO} 2$, oxygen saturation of mixed venous blood; PCI, percutaneous coronary intervention; POAF, postoperative atrial fibrillation; POD, post-operative day; PCWP, pulmonary capillary wedge pressure; RCT, random clinical trial; RyR2, ryanodine receptor 2; SVI, stroke volume index; SVT, supraventricular tachycardia; TNF- $\alpha$, tumor necrosis factor- $\alpha$; VT, ventricular tachycardia; VF, ventricular fibrillation.

\section{Funding}

This work was performed at Tsukuba University Hospital, Ibaraki, Japan. No financial support was received to conduct or publish this study.

\section{Disclosure}

The authors report no conflicts of interest in this work.

\section{References}

1. Nakashima M, Kanamaru M. Phase I study of ONO-1101, a new ultra short acting $\beta$ 1-blocking agent in healthy volunteers. $J$ Clin Ther Med. 2000;16(10):1531-1556.

2. Summary of product characteristics of Rapibloc. Available from: https://mri.cts-mrp.eu/Human/Downloads/NL_H_3368_002_ FinalSPC.pdf. Accessed February 27, 2020.

3. AOP and AMOMED announce the launch of RAPIBLOC ${ }^{\circledR}$ (Landiolol) in Germany and Austria. Available from: https://www.amomed.com/aopand-amomed-announce-the-launch-of-rapibloc-landiolol-in-germanyand-austria/?lang=en. 2017. Accessed February 27, 2020.

4. Approval for Corebeta ${ }^{\circledR}$ for Injection $12.5 \mathrm{mg}$ for Improvement of Image Quality in Coronary CT Angiography in Japan.

5. Approval for Additional Indication of Onoact ${ }^{\circledR} 50$ for injection, ShortActing Selective $\beta 1$ Blocker in Japan. Available from: https://www.ono.co. jp/eng/news/pdf/sm_cn131122.pdf. 2013. Accessed January 25, 2020 ..

6. ONO. Submits Supplemental Application of ONOACT ${ }^{\circledR}$ for Intravenous Infusion $50 \mathrm{mg} \cdot 150 \mathrm{mg}$, Short- Acting Selective $\beta 1$ Blocker for Indication of Ventricular Arrhythmia for a Partial Change in Approved Items of Manufacturing and Marketing Approval in Japan. Available from: https://www.ono.co.jp/eng/news/pdf/sm cn180730_1.pdf. 2018. Accessed January 25, 2020..

7. IGUCHI $\overline{\mathrm{S}}$, IWAMURA H, NISHIZAKI M, et al. Development of a highly cardioselective ultra short-acting BETA -blocker, ONO-1101. Chem Pharm Bull (Tokyo). 1992;40(6):1462-1469. doi:10.1248/ cpb.40.1462

8. Tsuchiya H, Mizogami M. Characteristic interactivity of landiolol, an ultra-short-acting highly selective $\beta 1$-blocker, with biomimetic membranes: comparisons with $\beta 1$-selective esmolol and non-selective propranolol and alprenolol. Front Pharmacol. 2013;4:150. doi:10.3389/ fphar.2013.00150 
9. Sasao J, Tarver SD, Kindscher JD, Taneyama C, Benson KT, Goto H. In rabbits, landiolol, a new ultra-short-acting beta-blocker, exerts a more potent negative chronotropic effect and less effect on blood pressure than esmolol. Can J Anaesth. 2001;48(10):985-989. doi:10.1007/BF03016588

10. Ikeshita K, Nishikawa K, Toriyama S, et al. Landiolol has a less potent negative inotropic effect than esmolol in isolated rabbit hearts. J Anesth. 2008;22(4):361-366. doi:10.1007/s00540-008-0640-4

11. Shibata S, Okamoto Y, Endo S, Ono K. Direct effects of esmolol and landiolol on cardiac function, coronary vasoactivity, and ventricular electrophysiology in guinea-pig hearts. J Pharmacol Sci. 2012;118 (2):255-265. doi:10.1254/jphs.11202FP

12. Tsunekawa K, Imawaka H, Yamamoto K, Shibakawa K, Hiraku S Studies on the metabolic fate of ultra short acting BETA 1 blocker ONO-1101. (3) metabolism and protein binding. Drug Metab Pharmacokinet. 1997;12(1):31-41. doi:10.2133/dmpk.12.31

13. Takahata T, Yasui-Furukori N, Sakamoto J, et al. Influence of hepatic impairment on the pharmacokinetics and pharmacodynamics of landiolol hydrochloride, an ultra-short-acting beta1-blocker. Drugs $R D$. 2005;6(6):385-394. doi:10.2165/00126839-200506060-00006

14. He Q, Shi M, Liu X, et al. Determination of landiolol, an ultra-shortacting $\beta_{1}$-receptor antagonist, in human plasma by liquid chromatography-tandem mass spectrometry. J Chromatogr B Analyt Technol Biomed Life Sci. 2012;891-892:7-11. doi:10.1016/j.jchromb.2011. 12.024

15. Wang $M$, Zhang Q, Hua W, Zhou W, Huang $M$, Wang $H$. Pharmacokinetics, pharmacodynamics, and safety of landiolol hydrochloride in healthy Chinese subjects. Drug Res (Stuttg). 2014;64 (3):141-145. doi:10.1055/s-0033-1354368

16. Krumpl G, Ulc I, Trebs M, Kadlecová P, Hodisch J. Pharmacokinetics and pharmacodynamics of two different landiolol formulations in a healthy Caucasian group. Eur J Pharm Sci. 2016;92:64-73. doi:10.1016/j.ejps.2016.06.022

17. Stix G, Wolzt M, Domanovits H, et al. Open-label two-dose pilot study of landiolol for the treatment of atrial fibrillation/atrial flutter in caucasian patients. Circ J. 2019;84(1):33-42. doi:10.1253/circj.CJ19-0661

18. Ojima T, Iwahashi M, Nakamori M, et al. Atrial fibrillation after esophageal cancer surgery: an analysis of 207 consecutive patients. Surg Today. 2014;44(5):839-847. doi:10.1007/s00595-013-0616-3

19. McCormack O, Zaborowski A, King S, et al. New-onset atrial fibrillation post-surgery for esophageal and junctional cancer: incidence, management, and impact on short- and long-term outcomes. Ann Surg. 2014;260(5):772-778. doi:10.1097/SLA.0000000000000960

20. Murthy SC, Law S, Whooley BP, Alexandrou A, Chu KM, Wong J. Atrial fibrillation after esophagectomy is a marker for postoperative morbidity and mortality. J Thorac Cardiovasc Surg. 2003;126 (4):1162-1167. doi:10.1016/S0022-5223(03)00974-7

21. Yoshida T, Furukita Y, Yamamoto Y, et al. A randomized, open label study of the efficacy of prophylactic 24-h low-dose landiolol for atrial fibrillation in transthoracic esophagectomy. Esophagus. 2017;14 (1):97-103. doi:10.1007/s10388-016-0553-5

22. Ojima T, Nakamori M, Nakamura M, et al. Randomized clinical trial of landiolol hydrochloride for the prevention of atrial fibrillation and postoperative complications after oesophagectomy for cancer. $\mathrm{Br}$ J Surg. 2017;104(8):1003-1009. doi:10.1002/bjs.10548

23. Horikoshi Y, Goyagi T, Kudo R, Kodama S, Horiguchi T, Nishikawa T. The suppressive effects of landiolol administration on the occurrence of postoperative atrial fibrillation and tachycardia, and plasma IL-6 elevation in patients undergoing esophageal surgery: a randomized controlled clinical trial. J Clin Anesth. 2017;38:111-116. doi:10.1016/j. jclinane.2017.01.036

24. Balik M, Sander M, Trimmel H, Heinz G. Landiolol for managing post-operative atrial fibrillation. Eur Heart J Suppl. 2018;20 (SupplA):A10-A14. doi:10.1093/eurheartj/sux036
25. Kugo Y, Nishi H, Sekiya N, Yamada M, Takahashi T. Postoperative atrial fibrillation in patients who underwent thoracic aortic surgery. Kyobu Geka. 2018;71(2):83-87.

26. Maisawa K, Yamazaki K, Ishitoya H, Shimamura Y. Effect of landiolol hydrochloride after off-pump coronary artery bypass. Asian Cardiovasc Thorac Ann. 2013;21(2):170-175. doi:10.1177/0218492312450865

27. Fujiwara H, Sakurai M, Namai A, Kawamura T. Effect of low-dose landiolol, an ultrashort-acting beta-blocker, on postoperative atrial fibrillation after CABG surgery. Gen Thorac Cardiovasc Surg. 2009;57(3):132-137. doi:10.1007/s11748-008-0341-9

28. Ito N, Tashiro $\mathrm{T}$, Morishige $\mathrm{N}$, et al. Safety and efficacy of an ultrashort-acting $\beta 1$-blocker on left ventricular dysfunction. Heart Surg Forum. 2012;15(4):E189-E194. doi:10.1532/HSF98.20111152

29. Tanaka K. Effects of landiolol on hemodynamic improvement and prevention of atrial fibrillation in the perioperative period of off-pump coronary artery bypass grafting. Kyobu Geka. 2010;63(3):175-183.

30. Wakamatsu H, Takase S, Sato Y, Seto Y, Kurosawa H, Yokoyama H. Effect of intra-operative low-dose infusion of landiolol hydrochloride on post-operative atrial fibrillation after off-pump coronary artery bypass grafting. Kyobu Geka. 2010;63(9):764-768.

31. Nishi H, Sakaguchi T, Miyagawa S, et al. Efficacy of landiolol hydrochloride for atrial fibrillation after open heart surgery. Heart Vessels. 2013;28(4):490-496. doi:10.1007/s00380-012-0263-4

32. Taenaka N, Kikawa S. Dose-dependent effect of landiolol, a new ultra-short-acting $\beta(1)$-blocker, on supraventricular tachyarrhythmias in postoperative patients. Clin Drug Investig. 2013;33(7):505-514. doi:10.1007/s40261-013-0093-x

33. Oka E, Iwasaki Y-K, Maru E, et al. Differential effectiveness of landiolol between atrial fibrillation and atrial flutter/atrial tachycardia patients with left ventricular dysfunction. Circ J. 2019;83 (4):793-800. doi:10.1253/circj.CJ-18-1131

34. Sakai M, Jujo S, Kobayashi J, Ohnishi Y, Kamei M. Use of low-dose $\beta(1)$-blocker for sinus tachycardia in patients with catecholamine support following cardiovascular surgery: a retrospective study. J Cardiothorac Surg. 2019;14(1):145. doi:10.1186/s13019-0190966-z

35. Nagaoka E, Arai H, Tamura K, Makita S, Miyagi N. Prevention of atrial fibrillation with ultra-low dose landiolol after off-pump coronary artery bypass grafting. Ann Thorac Cardiovasc Surg. 2014;20 (2):129-134. doi:10.5761/atcs.oa.12.02003

36. Fujii M, Bessho R, Ochi M, Shimizu K, Terajima K, Takeda S. Effect of postoperative landiolol administration for atrial fibrillation after off pump coronary artery bypass surgery. J Cardiovasc Surg (Torino). 2012;53(3):369-374.

37. Ogawa S, Okawa Y, Goto Y, Aoki M, Baba H. Perioperative use of a beta blocker in coronary artery bypass grafting. Asian Cardiovasc Thorac Ann. 2013;21(3):265-269. doi:10.1177/ 0218492312451166

38. Sezai A, Minami K, Nakai T, et al. Landiolol hydrochloride for prevention of atrial fibrillation after coronary artery bypass grafting: new evidence from the PASCAL trial. J Thorac Cardiovasc Surg. 2011;141(6):1478-1487. doi:10.1016/j.jtcvs.2010.10.045

39. Sezai A, Nakai T, Hata M, et al. Feasibility of landiolol and bisoprolol for prevention of atrial fibrillation after coronary artery bypass grafting: a pilot study. J Thorac Cardiovasc Surg. 2012;144 (5):1241-1248. doi:10.1016/j.jtcvs.2012.06.042

40. Sakaguchi M, Sasaki Y, Hirai H, et al. Efficacy of landiolol hydrochloride for prevention of atrial fibrillation after heart valve surgery. Int Heart J. 2012;53(6):359-363. doi:10.1536/ihj.53.359

41. Sezai A, Osaka S, Yaoita H, et al. Safety and efficacy of landiolol hydrochloride for prevention of atrial fibrillation after cardiac surgery in patients with left ventricular dysfunction: prevention of atrial fibrillation after cardiac surgery with landiolol hydrochloride for left ventricular dysfunction (PLATON) trial. J Thorac Cardiovasc Surg. 2015;150(4):957-964. doi:10.1016/j.jtcvs.2015.07.003 
42. Sakamoto A, Kitakaze M, Takamoto S, et al. Landiolol, an ultra-short -acting $\beta_{1}$-blocker, more effectively terminates atrial fibrillation than diltiazem after open heart surgery: prospective, multicenter, randomized, open-label study (JL-KNIGHT study). Circ J. 2012;76 (5):1097-1101. doi:10.1253/circj.cj-11-1332

43. Tamura T, Yatabe T, Yokoyama M. Prevention of atrial fibrillation after cardiac surgery using low-dose landiolol: a systematic review and meta-analysis. J Clin Anesth. 2017;42:1-6. doi:10.1016/j. jclinane.2017.07.009

44. Kiyokuni M, Konishi M, Sakamaki K, et al. Beneficial effect of early infusion of landiolol, a very short-acting beta-1 adrenergic receptor blocker, on reperfusion status in acute myocardial infarction. Int J Cardiol. 2016;221:321-326. doi:10.1016/j.ijcard.2016.07.076

45. Hoshi T, Sato A, Nishina H, et al. Acute hemodynamic effects of landiolol, an ultra-short-acting beta-blocker, in patients with acute coronary syndrome: preliminary study. $J$ Cardiol. 2012;60 (4):252-256. doi:10.1016/j.jjcc.2012.06.010

46. Hanada K, Higuma T, Nishizaki F, et al. Randomized study on the efficacy and safety of landiolol, an ultra-short-acting $\beta 1$-adrenergic blocker, in patients with acute myocardial infarction undergoing primary percutaneous coronary intervention. Circ J. 2012;76 (2):439-445. doi:10.1253/circj.CJ-11-0947

47. Park H, Otani H, Noda T, et al. Intracoronary followed by intravenous administration of the short-acting $\beta$-blocker landiolol prevents myocardial injury in the face of elective percutaneous coronary intervention. Int J Cardiol. 2013;167(4):1547-1551. doi:10.1016/j. ijcard.2012.04.096

48. Hoole SP, Heck PM, Sharples L, et al. Cardiac remote ischemic preconditioning in coronary stenting (CRISP stent) study. a prospective, randomized control trial. Circulation. 2009;119 (6):820-827. doi:10.1161/CIRCULATIONAHA.108.809723

49. Matsui Y, Suzuki A, Shiga T, Arai K, Hagiwara N. Effects of intravenous landiolol on heart rate and outcomes in patients with atrial tachyarrhythmias and acute decompensated heart failure: a single-center experience. Drugs - Real World Outcomes. 2019;6 (1):19-26. doi:10.1007/s40801-019-0149-1

50. Kobayashi S, Murakami W, Myoren T, et al. A low-dose $\beta_{1}$-blocker effectively and safely slows the heart rate in patients with acute decompensated heart failure and rapid atrial fibrillation. Cardiology. 2014;127(2):105-113. doi:10.1159/000355312

51. Kiuchi S, Aikawa H, Hisatake S, et al. Efficacy of intravenous administration of landiolol in patients with acute heart failure and supraventricular tachyarrhythmia. J Clin Med Res. 2017;9 (5):426-432. doi:10.14740/jocmr2954w

52. Kobayashi S, Susa T, Tanaka T, et al. Low-dose $\beta$-blocker in combination with milrinone safely improves cardiac function and eliminates pulsus alternans in patients with acute decompensated heart failure. Circ J. 2012;76(7):1646-1653. doi:10.1253/circj.CJ-12-0033

53. Kobayashi S, Susa T, Ishiguchi $H$, et al. A low-dose $\beta 1$-blocker in combination with milrinone improves intracellular $\mathrm{Ca} 2+$ handling in failing cardiomyocytes by inhibition of milrinone-induced diastolic Ca2+ leakage from the sarcoplasmic reticulum. PLoS One. 2015;10 (1):e0114314-e0114314. doi:10.1371/journal.pone.0114314

54. Nagai R, Kinugawa K, Inoue $H$, et al. Urgent management of rapid heart rate in patients with atrial fibrillation/flutter and left ventricular dysfunction: comparison of the ultra-short-acting $\beta 1$-selective blocker landiolol with digoxin (J-Land Study). Circ J. 2013;77(4):908-916. doi:10.1253/circj.cj-12-1618

55. Wada Y, Aiba T, Tsujita Y, et al. Practical applicability of landiolol, an ultra-short-acting $\beta 1$-selective blocker, for rapid atrial and ventricular tachyarrhythmias with left ventricular dysfunction. J Arrhythmia. 2016;32(2):82-88. doi:10.1016/j.joa.2015.09.002

56. Adachi T, Sato A, Baba M, et al. Novel use of the ultra-short-acting intravenous $\beta 1$-selective blocker landiolol for supraventricular tachyarrhythmias in patients with congestive heart failure. Heart Vessels. 2014;29(4):464-469. doi:10.1007/s00380-013-0377-3
57. Calvin JE, Driedger AA, Sibbald WJ. An assessment of myocardial function in human sepsis utilizing ECG gated cardiac scintigraphy. Chest. 1981;80(5):579-586. doi:10.1378/chest.80.5.579

58. Vieillard-Baron A, Caille V, Charron C, Belliard G, Page B, Jardin F. Actual incidence of global left ventricular hypokinesia in adult septic shock. Crit Care Med. 2008;36(6):1701-1706. doi:10.1097/ CCM.0b013e318174db05

59. Tang C, Yang J, Wu -L-L, Dong L-W, Liu M-S. Phosphorylation of $\beta$-adrenergic receptor leads to its redistribution in rat heart during sepsis. Am J Physiol Integr Comp Physiol. 1998;274(4):R1078R1086. doi:10.1152/ajpregu.1998.274.4.R1078

60. Hunter JD, Doddi M. Sepsis and the heart. Br J Anaesth. 2010;104 (1):3-11. doi:10.1093/bja/aep339

61. Shepherd RE, Lang CH, McDonough KH. Myocardial adrenergic responsiveness after lethal and nonlethal doses of endotoxin. Am J Physiol Circ Physiol. 1987;252(2):H410-H416. doi:10.1152/ ajpheart.1987.252.2.H410

62. Gattinoni L, Brazzi L, Pelosi P, et al. A trial of goal-oriented hemodynamic therapy in critically ill patients. $N$ Engl J Med. 1995;333 (16):1025-1032. doi:10.1056/NEJM199510193331601

63. Hayes MA, Timmins AC, Yau E, Palazzo M, Hinds CJ, Watson D. Elevation of systemic oxygen delivery in the treatment of critically Ill patients. N Engl J Med. 1994;330(24):1717-1722. doi:10.1056/ NEJM199406163302404

64. Schmittinger CA, Torgersen C, Luckner G, Schröder DCH, Lorenz I, Dünser MW. Adverse cardiac events during catecholamine vasopressor therapy: a prospective observational study. Intensive Care Med. 2012;38(6):950-958. doi:10.1007/s00134-012-2531-2

65. Morelli A, Ertmer C, Westphal M, et al. Effect of heart rate control with esmolol on hemodynamic and clinical outcomes in patients with septic shock: a randomized clinical trial. JAMA - J Am Med Assoc. 2013;310(16):1683-1691. doi:10.1001/jama.2013.278477

66. Wei C, Louis H, Schmitt M, et al. Effects of low doses of esmolol on cardiac and vascular function in experimental septic shock. Crit Care. 2016;20(1):1-10. doi:10.1186/s13054-016-1580-2

67. Du W, Liu D, Long Y, Wang X. The $\beta$-blocker esmolol restores the vascular waterfall phenomenon after acute endotoxemia*. Crit Care Med. 2017;45(12):e1247-e1253. doi:10.1097/CCM.000000000000 2721

68. Aboab J, Sebille V, Jourdain M, et al. Effects of esmolol on systemic and pulmonary hemodynamics and on oxygenation in pigs with hypodynamic endotoxin shock. Intensive Care Med. 2011;37 (8):1344-1351. doi:10.1007/s00134-011-2236-y

69. Seki Y, Jesmin S, Shimojo N, et al. Significant reversal of cardiac upregulated endothelin-1 system in a rat model of sepsis by landiolol hydrochloride. Life Sci. 2014;118(2):357-363. doi:10.1016/j. lfs.2014.04.005

70. Hagiwara S, Iwasaka H, Maeda H, Noguchi T. Landiolol, an ultrashort-acting $\beta 1$-adrenoceptor antagonist, has protective effects in an lps-induced systemic inflammation model. Shock. 2009;31 (5):515-520. doi:10.1097/SHK.0b013e3181863689

71. Kiyonaga N, Moriyama T, Kanmura Y. Effects of landiolol in lipopolysaccharide-induced acute kidney injury in rats and in vitro. Shock. 2019;52(5):e117-e123. doi:10.1097/SHK.0000000000001306

72. Ogura Y, Jesmin S, Yamaguchi N, et al. Potential amelioration of upregulated renal HIF-1alpha-endothelin-1 system by landiolol hydrochloride in a rat model of endotoxemia. Life Sci. 2014;118 (2):347-356. doi:10.1016/j.1fs.2014.05.007

73. Matsuishi Y, Jesmin S, Kawano S, et al. Landiolol hydrochloride ameliorates acute lung injury in a rat model of early sepsis through the suppression of elevated levels of pulmonary endothelin-1. Life Sci. 2016:166. doi:10.1016/j.1fs.2016.10.010.

74. Kurita T, Kawashima S, Morita K, Nakajima Y. Use of a short-acting $\beta 1$ blocker during endotoxemia may reduce cerebral tissue oxygenation if hemodynamics are depressed by a decrease in heart rate. Shock. 2017;47(6):765-771. doi:10.1097/SHK.0000000000000795 
75. Mathieu C, Desrois M, Kober F, et al. Sex-mediated response to the beta-blocker landiolol in sepsis: an experimental, randomized study. Crit Care Med. 2018;46(7):e684-e691. doi:10.1097/CCM.0000000000 003146

76. Matyal R, Mahmood F, Panzica P, et al. Sex-related differences in outcome after high-risk vascular surgery after the administration of $\beta$ adrenergic-blocking drugs. J Cardiothorac Vasc Anesth. 2008;22 (3):354-360. doi:10.1053/j.jvca.2007.12.021

77. Yoshida Y, Hongo T, Sakamoto A, Ogawa R. Successful management of tachycardiac atrial fibrillation in a septic patient with landiolol. Anesth Analg. 2005;100(1):294. doi:10.1213/01.ANE.0000140814.28118.6F

78. Okajima M, Takamura M, Taniguchi T. Landiolol, an ultra-shortacting $\beta 1$-blocker, is useful for managing supraventricular tachyarrhythmias in sepsis. World J Crit Care Med. 2015;4(3):251-257. doi:10.5492/wjccm.v4.i3.251

79. Unger M, Morelli A, Singer M, et al. Landiolol in patients with septic shock resident in an intensive care unit (LANDI-SEP): study protocol for a randomized controlled trial. Trials. 2018;19(1):637. doi:10.1186/s13063-018-3024-6

80. Wiest DB, Garner SS, Uber WE, Sade RM. Esmolol for the management of pediatric hypertension after cardiac operations. J Thorac Cardiovasc Surg. 1998;115(4):890-897. doi:10.1016/S0022-5223(98) 70371-X

81. Tabbutt S, Nicolson SC, Adamson PC, et al. The safety, efficacy, and pharmacokinetics of esmolol for blood pressure control immediately after repair of coarctation of the aorta in infants and children: a multicenter, double-blind, randomized trial. J Thorac Cardiovasc Surg. 2008;136(2):321-328. doi:10.1016/j.jtcvs.2007.09.086
82. Nakagawa R, Fujita S, Shimao A, Futatani T, Hatasaki K. Successful treatment of neonatal idiopathic ventricular tachycardia with landiolol hydrochloride. Pediatr Int. 2019;61(10):1048-1050. doi:10. 1111/ped.13969

83. Fujita S, Futatani T, Kubo T, et al. Virus myocarditis in a 1-monthold boy presenting as two types of paroxysmal supraventricular tachycardia. Pediatr Int. 2017;59(5):627-632. doi:10.1111/ped.13261

84. Miyake K, Fujita Y, Yoshizawa S, et al. Effects of landiolol on refractory tachyarrhythmia after total cavopulmonary connection: a retrospective, observational, cohort study. J Anesth. 2016;30 (2):331-336. doi:10.1007/s00540-015-2119-4

85. Tokunaga C, Hiramatsu Y, Kanemoto S, et al. Effects of landiolol hydrochloride on intractable tachyarrhythmia after pediatric cardiac surgery. Ann Thorac Surg. 2013;95(5):1685-1688. doi:10.1016/j. athoracsur.2013.01.057

86. Yoneyama F, Tokunaga C, Kato H, et al. Landiolol hydrochloride rapidly controls junctional ectopic tachycardia after pediatric heart surgery. Pediatr Crit Care Med. 2018;19(8):713-717. doi:10.1097/ PCC.0000000000001573

87. Sumitomo N, Horigome H, Miura M, et al. Study design for control of HEART rate in inFant and child tachyarrhythmia with heart failure using landiolol (HEARTFUL): a prospective, multicenter, uncontrolled clinical trial. J Cardiol. 2017;70(3):232-237. doi:10.1016/j. jjcc.2016.12.002
Vascular Health and Risk Management

\section{Publish your work in this journal}

Vascular Health and Risk Management is an international, peerreviewed journal of therapeutics and risk management, focusing on concise rapid reporting of clinical studies on the processes involved in the maintenance of vascular health; the monitoring, prevention and treatment of vascular disease and its sequelae; and the involvement

\section{Dovepress}

of metabolic disorders, particularly diabetes. This journal is indexed on PubMed Central and MedLine. The manuscript management system is completely online and includes a very quick and fair peerreview system, which is all easy to use. Visit http://www.dovepress. com/testimonials.php to read real quotes from published authors. 